\title{
'I FELT LIKE SHE OWNS ME': EXPLOITATION AND UNCERTAINTY IN THE LIVES OF LABOUR TRAFFICKING VICTIMS IN IRELAND
}

\author{
David M. Doyle*, Clíodhna Murphy, Muiread Murphy, \\ Pablo Rojas Coppari and Rachel J. Wechsler
}

Although the law relating to 'modern slavery' has received increased attention in recent years, the perspectives of labour trafficking victims rarely feature in the literature. The article explores how this vulnerable group experiences the Irish anti-trafficking regime in practice. Drawing on 15 semi-structured interviews, it shows that victims of labour trafficking in Ireland receive minimal assistance from the State at every stage of the trafficking cycle, from prevention and identification to seeking redress for harms suffered. The lived experiences of the participants cut across the spheres of employment, criminal and immigration law, stretching well beyond the 'silo' of the anti-trafficking framework. The article concludes by suggesting that victims' perspectives are an essential part of evidence-based policy responses to the multi-faceted phenomenon of severe labour exploitation, as well as a comprehensive analytical framework. It agrees that existing critiques of the anti-trafficking paradigm are well-founded, but argues that they should also take account of the practical benefits for individuals who are granted 'victim of trafficking' status.

Key Words: labour trafficking, victims, Ireland

\section{Introduction}

Human trafficking, slavery, servitude and forced labour have been high on the international agenda in the '(t)he neo-abolitionist era' of the 21st century (Allain 2012). As a result, these forms of 'modern slavery' (International Labour Organization [ILO] 2017: 9) are now the subject of an impressive legal acquis, and states have broadly drawn duties to identify, assist and protect individuals who are victims of human trafficking as well as other forms of severe labour exploitation (Stoyanova 2017: 2). ${ }^{1}$ Recently adopted measures, specifically designed to combat trafficking in human beings, include a United Nations Protocol (2000); a Council of Europe Convention (2005) and various European Union (EU) Directives (2004, 2011). These sit alongside older international treaties prohibiting slavery and forced labour (ILO 1930, No. 29; Ollus 2015). Moreover, Article 4 of the European Convention on Human Rights (ECHR) imposes wide-ranging positive obligations on states to provide individuals with practical and effective

\footnotetext{
*David M. Doyle, Department of Law, Maynooth University, County Kildare, Ireland; david.doyle@mu.ie; Clíodhna Murphy, Department of Law, Maynooth University, County Kildare, Ireland; Muiread Murphy, Department of Law, Maynooth University, Maynooth, County Kildare, Ireland; Pablo Rojas Coppari, Department of Sociology, Maynooth University, Maynooth, County Kildare, Ireland; Rachel J. Wechsler, New York University School of Law, New York, NY 10012, USA

${ }^{1}$ The ILO (2017: 9) notes that 'modern slavery covers a set of specific legal concepts including forced labour, debt bondage, forced marriage, other slavery and slavery like practices, and human trafficking. Although modern slavery is not defined in law, it is used as an umbrella term that focuses attention on commonalities across these legal concepts.'
} 
protection against trafficking and severe labour exploitation (Ranstev: para. 285; Stoyanova 2014; Turner 2015; Milano 2017)).

Ireland's legal anti-trafficking framework has been shaped by these international and EU law instruments. However, it is well-known that there are ongoing and serious problems with the practical implementation of the anti-trafficking regime. For example, although the Irish authorities identified 219 suspected trafficking victims in the 3-year period between 2014 and 2016, there has not been a successful prosecution for trafficking offences in Ireland since 2013 (United States Department of State (USDS) 2017: 217). These issues, inter alia, have been consistently highlighted by domestic non-governmental organizations (NGOs) and international bodies (Group of Experts against Trafficking in Human Beings (GRETA) 2015; 2017; Immigrant Council of Ireland (ICI) 2011; 2017; Irish Human Rights and Equality Commission 2016; Operation in Europe (OSCE) 2013), including through the downgrading of Ireland's status from Tier 1 to Tier 2 among countries worldwide for its approach to trafficking by the annual US Department of State Trafficking in Persons Report (USDS 2018: 235). Most recently, the head of the national labour enforcement agency (The Workplace Relations Commission (WRC)) shared the view of labour inspectors that 'you're only ever about 5 miles from somebody in effective slavery in Ireland'.2

The shortcomings of the Irish system are replicated across Europe and beyond. In 2014, the EU Fundamental Rights Agency stated that '(s)evere labour exploitation of workers who have moved within or into the EU is common, although it often remains invisible to the public' (European Union Fundamental Rights Agency (FRA) 2015: 12). On a global scale, the ILO confirms that the number of investigations, prosecutions and convictions for modern slavery-type crimes is 'very small relative to the scale of the overall problem' (ILO 2017: 53). The practical and normative effects of the legal instruments thus appear to be limited. Indeed, the interaction and overlaps between slavery, servitude, forced labour and trafficking-as well as non-legal terms such as 'unfree labour' (Strauss 2012; Fudge and Strauss 2013; Yea and Chok 2018) - has led to what Paz-Fuchs describes as a 'conceptual quagmire' (Paz-Fuchs 2016: 760).

In response to this quagmire, Paz-Fuchs develops markers or 'badges' as a means to break down and explain the now-widespread concept of 'modern slavery' (Paz-Fuchs 2016: 762). Doctrinal scholarship in the field has done the important work of analysing, conceptualizing and critiquing recent developments in international and EU law (Allain 2012; Stoyanova 2017). Another strand of literature has charted the way in which states have instrumentalized anti-trafficking and anti-slavery discourse as a justification for tighter immigration controls (O'Connell-Davidson and Anderson 2006; Anderson 2012; Gadd and Broad 2018). Many have questioned the usefulness of the concept of human trafficking for actually diminishing abuses (Noll 2007; Hathaway 2008). Despite this growing body of scholarship, there has been little criminological or sociolegal research drawing on interviews with persons trafficked for purposes of labour exploitation (Cameron and Newman 2008; Mantouvalou 2015; Davies 2018). The ongoing failure of policymakers and legislators to consider the crime of labour trafficking from the perspective of the victim (Jordan 2002: 29) is thus matched by a

\footnotetext{
${ }^{2}$ 'Some foreign nationals in Ireland work in "conditions that are close to slavery"', The Journal, (11 February 2018) available at http://www.thejournal.ie/working-conditions-close-to-slavery-3846399-Feb2018/.
} 
lack of literature in this area. In the Irish context, this forms part of a broader problem within the criminal process of a 'lack of knowledge among criminal justice agencies and actors about the needs of victims of crime' (Kilcommins et al. 2018: 6).

This article is based on the premise that 'top-down' approaches to analysing severe labour exploitation should be complemented by 'bottom-up' analysis rooted in the experiences of victims. We argue that if governments are serious about practically implementing the broad-brush obligations imposed by international, EU and domestic law, they must have access to information on the background, lived experiences and needs of trafficked persons. Although domestic policy in Ireland and elsewhere seeks to provide victims 'with a tailored response that fits their vulnerability, addresses the impact this crime has had on them and helps us to bring their abusers to justice' (DJE 2016: 4-5), there is at present no formal consultative process by which victims can provide their views on the system of victim identification or protection in Ireland. The article explores how victims experience the anti-trafficking regime in Ireland in practice, by drawing on interviews with 15 participants. The analysis reveals a combination of legal, administrative and practical obstacles to a functioning anti-trafficking regime, which would accommodate the 'lived experiences and realities of victimhood' (Kilcommins et al. 2018: 6).

The article starts by outlining the methodology of the qualitative study before briefly setting out the Irish legal and policy context. It then presents our findings in three parts: barriers to reporting and identification, victim support and protection, and victims' perspectives on assisting authorities with prosecutions. The common thread running through the testimonies is the minimal nature of the assistance received from the State at every stage of the trafficking cycle, from prevention and identification to seeking redress for harms suffered. Although the participants reported meeting 'kind' and 'helpful' police officers, immigration officials and NGO staff, often those people 'didn't have a way to help' or there was a 'limit for what they can do' (Female, South Africa, T4; Female, South Africa, T12) in a haphazard and inadequate system. Overall, for most of those interviewed for this study, the State provided little more than temporary visas allowing victims to stay in Ireland on a precarious basis, with basic subsistence welfare support. Nonetheless, the research also shows that even this very limited support offered by the State is perceived by victims of trafficking as being of benefit. The article concludes by suggesting that victims' perspectives are an essential part of evidence-based policy responses to the multi-faceted phenomenon of trafficking for the purposes of labour exploitation. Finally, it argues that existing conceptual frameworks for analysing modern slavery must be developed to take account of the 'bottomup' finding that identified victims of labour trafficking derive some benefit in practice from the anti-trafficking framework.

\section{Methodology}

Our analysis draws on semi-structured interviews conducted with 15 people who were identified by the Migrant Rights Centre Ireland (MRCI) case workers as victims of trafficking for the purposes of labour exploitation. Although trafficking indicators were identified in all of these cases, only seven of the participants had been granted official victim of trafficking status. The interviews were arranged by MRCI and conducted on their premises, or at 
an alternative location nominated by the participant. The vulnerability of the interviewees was a primary concern and the interviews were conducted in line with international best practice (World Health Organization 2003; Van Liempt and Bilger 2009) and as sensitively as possible. Research has shown that 'trafficked people generally come from places where economic and social difficulties make migration a popular choice' (Friesendorf 2007: 381) and our interviews suggest that Ireland is not an exception in this regard. The participants came from India, Kenya, Malawi, Nigeria, Pakistan, the Philippines, South Africa and Zimbabwe (see Table 1). Accordingly, a reflexive analysis of how ethnicity and race shaped the interactions between the researchers and the 'researched' was vital (Emirbayer and Desmond 2012). The duration of the interviews ranged from 31 to 97 minutes.

Most States now recognize that trafficked persons have special rights (Gallagher 2010: 279). However, as Ann Jordan wrote in 2002, 'governments consistently fail to consider the crime from the perspective of the trafficked person and are particularly inept at understanding the problem from the perspective of trafficked women' (Jordan 2002: 29). With this statement in mind, interviews were conducted with 13 female and two male trafficking victims. The gender of the interviewer did not always match that of the participant, but this is less of a concern for research with labour trafficking victims than it is with sex trafficking victims. Each of the interviewees had left their trafficking situation by the time these interviews were conducted. The age range of the victims varied from 19 to 55 years when they accessed the services of MRCI. Thirteen interviewees were trafficked to Ireland either by a relative, a former employer, an acquaintance or a person known to the victim's family, friends or previous employers.

TABLE 1 Socio-demographic data of research participants

\begin{tabular}{|c|c|c|c|c|}
\hline $\begin{array}{l}\text { Nationality/ } \\
\text { country of origin }\end{array}$ & $\begin{array}{l}\text { Trafficking for } \\
\text { the purposes } \\
\text { of labour } \\
\text { exploitation } \\
\text { (TLE) indicators }\end{array}$ & $\begin{array}{l}\text { Official victim } \\
\text { of trafficking } \\
\text { (VOT) status }\end{array}$ & Traffickers & $\begin{array}{l}\text { Employment } \\
\text { sector }\end{array}$ \\
\hline Pakistani & Yes & No & Acquaintance & Domestic \\
\hline South African & Yes & No & $\begin{array}{l}\text { Met employer through online } \\
\text { au pair recruitment site }\end{array}$ & Domestic \\
\hline Filipino & Yes & Yes & Applied to job advert in paper & Domestic \\
\hline Filipino & Yes & No & Former employers & Domestic \\
\hline Nigerian & Yes & No & $\begin{array}{l}\text { A Nigerian woman her father } \\
\text { met in Nigeria }\end{array}$ & Domestic \\
\hline Nigerian & Yes & No & Aunt & Domestic \\
\hline Nigerian & Yes & Yes & Former employers & Domestic \\
\hline Malawian & Yes & No & Friends of a friend & Domestic \\
\hline Kenyan & Yes & Yes & Friend of former employer & Domestic \\
\hline South African & Yes & Yes & Aunt & Domestic \\
\hline Filipino & Yes & Yes & Cousin & Domestic \\
\hline South African & Yes & Yes & Friend of former employer & Domestic \\
\hline South African & Yes & Yes & Family acquaintance & Domestic \\
\hline Indian & Yes & $\begin{array}{l}\text { Not applied } \\
\text { for }\end{array}$ & $\begin{array}{l}\text { Friend in collaboration with } \\
\text { an Irish bed and breakfast } \\
\text { owner }\end{array}$ & Domestic \\
\hline Pakistani & Yes & No & Family & Restaurant \\
\hline
\end{tabular}


It must be acknowledged that the perspectives of these interviewees may not necessarily be representative of the experiences of all labour trafficking victims in Ireland. As shown in Table 1, most of the participants suffered exploitation within the domestic work sector, which are predominantly female. It is well-established-at both the domestic level in Ireland and across Europe-that female migrant domestic workers are at particular risk of severe labour exploitation (Anti-Human Trafficking Unit (AHTU) 2009: 25; GRETA 2017: 7; ILO 2017: 10). MRCI has long experience of working with domestic and care workers through its Domestic Workers Action Group and helped to facilitate the conditions for activism among domestic workers, which resulted in greater confidence in engaging with the study. Victims who contact MRCI for assistance and rehabilitation may be more empowered, informed or 'systematically different from those who do not' (Tyldum and Brunovskis 2005: 25; Mantouvalou 2015: 339). As Baldwin et al. point out, the circumstances and characteristics of victims "who successfully leave a situation of trafficking and subsequently connect with support services likely vary from those of individuals who remain under the control of traffickers, who escape but remain socially isolated or unable to access services, and those who choose not to pursue aftercare services' (Baldwin et al. 2015: 1178). This research has not heard these 'more complex testimonies' (Agustin 2005: 106): such an investigation would have been methodologically impossible given the difficulties in designing a 'sampling frame for a hidden population' (Di Nicola et al. 2009: 25).

\section{The Legal and Policy Context of Ireland's Anti-Trafficking Regime}

Legislation creating offences pertaining to human trafficking was first introduced in September 2000 (Illegal Immigrants (Trafficking) Act 2000), with the early legislation focusing on criminalizing people smuggling. The Criminal Law (Human Trafficking) Act 2008 (2008 Act) comprises the primary legislation. Reflecting the approach taken in the international texts, the crime of trafficking under the 2008 Act has three constitutive elements - action, means and exploitation:

- the action of: procurement, recruitment, transportation, transport, harbouring or receipt of persons, providing accommodation or employment ${ }^{3}$;

- by means of: the threat or use of force or other forms of coercion, abduction, fraud, deception, the abuse of power or a position of vulnerability or the giving or receiving of payments or benefits to achieve the consent of a person having control over another person ${ }^{4}$;

- for the purpose of exploitation, (including labour exploitation, sexual exploitation, the removal of organs, or forced criminal activities engaged in for financial gain). ${ }^{5}$

Under this definition, and despite popular belief to the contrary, no transnational dimension to the crime is required: trafficking can take place entirely within Ireland. This means that cross-border trafficking, slavery, servitude and forced labour-which are treated as distinct phenomena in the United Kingdom's Modern Slavery Act 2015, e.g.- -all fall within the umbrella definition of 'trafficking' provided under the Irish framework. 'Administrative

\footnotetext{
${ }^{3}$ Section 1 of the Criminal Law (Human Trafficking) Act 2008, as amended (hereinafter '2008 Act'). ${ }^{4}$ Section 4 of the 2008 Act.

${ }^{5}$ Section 1 of the 2008 Act.
} 
Immigration Arrangements' ${ }^{6}$ supplement the primary legislation and provide further detail of immigration-related support for non-European Economic Area citizen victims. They provide for a 60-day period of recovery and reflection for victims ${ }^{7}$ and a six-month temporary residence permit for victims who assist the authorities with investigation or prosecution. ${ }^{8}$ From an enforcement perspective, a dedicated Anti-Human Trafficking Unit (AHTU) was first established by an Garda Síochána (the Irish police force) in 2009 (MRCI 2014: 2). In 2016, a key policy document in the form of the Second National Action Plan to Prevent and Combat Human Trafficking in Ireland (SNAP) was adopted and was broadly welcomed by NGOs working in the sector. Among other things, the SNAP commits the State to re-examining the victim identification process by outlining the role played in this process by all stakeholders, including NGOs; there is also a commitment to a review of the National Referral Mechanism, encompassing the quality of the services provided to victims.

\section{Trafficking for the purposes of labour exploitation}

As seen in the earlier definition, labour exploitation is one of the forms of exploitation that the 2008 Act specifically addresses. It includes subjecting a person to 'forced labour' (including begging); 'forcing him or her to render services to another' or the 'enslavement of the person or subjecting him or her to servitude or a similar condition or state'. 9 'Forced labour' is defined as a work or service that is exacted from a person under the menace of any penalty and for which the person has not offered himself or herself voluntarily. ${ }^{10}$ Unlike the approach taken in the United Kingdom in the Modern Slavery Act $2015,{ }^{11}$ there are no separate specific offences of servitude and forced labour in Irish law, independent of the anti-trafficking regime, meaning that labour exploitation scenarios that do not satisfy the stringent three-part trafficking test of action-means-exploitation will not ground a prosecution. As Coghlan and Wylie (2011: 1513) argue in their empirically grounded research on trafficking for forced labour in Ireland, 'Few cases "tick all the boxes" of a rigid definition of trafficking, yet the exploitation of migrant workers is rife'. The Council of Europe GRETA has noted that a feature of the system is that there is often a preference to avoid prosecuting trafficking offences and to charge traffickers with lesser offences instead (GRETA 2017: para. 223).

Having briefly outlined the legal and policy context of the study, the following sections engage in a thematic discussion of the qualitative findings.

\section{Barriers to Identification and Reporting}

\section{Ineffective identification procedures}

An adequate and efficient victim identification procedure is 'crucial as it guarantees the safety of the victims and removes them from the control of the traffickers' (Stapleton

\footnotetext{
${ }^{64}$ Administrative Immigration Arrangements for the Protection of Victims of Human Trafficking,' 9 March 2011. Available at http://www.inis.gov.ie/en/INIS/Pages/PB08000021 (last accessed 12 December 2017).

${ }^{7}$ Paras 5-11.

${ }^{8}$ Paras 12-18.

${ }^{9}$ Section 1 of the 2008 Act.

${ }^{10}$ Section 1 of the 2008 Act.

${ }^{11}$ Section 1 (slavery, servitude and forced labour); and Section 2 (human trafficking) of the Modern Slavery Act 2015.
} 
2011: 186). It should also ensure that identification decisions are made without delay and that victims are neither re-traumatized during the process nor criminalized for activities undertaken during their trafficking ordeal. Nonetheless, victim identification remains a major challenge in many states (OSCE 2013: 3), and identification rates in Ireland are relatively low (95 detected trafficking victims in 2016) (USDS 2017: 217). True, 'identifying a trafficked person is a complex and time-consuming process' (OSCE 2011: 18), but in Ireland, there is an absence of 'a uniform way of identifying victims of trafficking' (Stapleton 2011: 199; Joyce and Quinn 2014: 2). Some of the difficulties in practice are highlighted in the case of one of the participants; here, the police visited the house in which she worked for immigration-related reasons and asked the victim questions about her immigration status. The employer instructed the victim to lie and tell the police that they were related-which she did. The police left the house without further action. When the victim subsequently escaped her situation, she met the same police officers again. She states: 'They said "we sensed that there was, something was going on, but we didn't figure out what was it"'. The participant's view is that they should have talked to her in private, away from her trafficker (Female, Malawi, T7). Another interviewee also reported that the police had visited his workplace to check on a broken window, but that 'the manager say to me I can't talk to the police as I have no visa' (Male, India, T10).

The process of victim identification is 'currently conflated with the criminal investigation and as a consequence the standard of proof used to identify a victim is the same as for a decision on whether there was sufficient evidence to prosecute an offender' (DJE 2015: 3). Such a procedure (which often requires victims to give multiple accounts of their trafficking experience to Gardaí) may not only result in re-victimization, but also in a 'violation of their rights' (OSCE 2011: 26). This also contributes to the often long delay before an initial decision is delivered on identification (GRETA 2017: 30). One participant reported that providing the statement to Gardaí took five months in total, due to the fact that she was traumatized and found it difficult to talk about her experiences (Female, Philippines, T13).

Among other problems, victims may not be familiar with the terminology of human trafficking (Elliot 2014: 185) and 'struggle to define their experiences as human trafficking' (Farrell and Pfeffer 2014: 50). One participant, e.g., lodged an asylum claim because her first interview was with the asylum applications agency, who asked her if she wished to claim asylum. Only when she spoke to her lawyer did she realize that human trafficking was more appropriate to her situation (Female, South Africa, T12). Other interviewees had little or no knowledge of employment rights or the immigration system in Ireland on arrival (Female, Philippines, T13). One participant was particularly forthright about her lack of knowledge: 'to be honest, when I came here there was no information. I didn't even know anything about visa, about legislation' (Female, Nigeria, T3). A striking common feature of their experiences was the level of control that employers exercised over their passage to Ireland, their initial entry and their immigration status. In one case, the employer originally told the worker that she and some other workers would be going to Britain but then changed this to Ireland (Female, Kenya, T6). In all 15 cases, the employers handled immigration visas' issues and the victims had little input. This is encapsulated in the words of one participant: 'when they brought me here they told me that they are going to do everything for me. I didn't know I was undocumented' (Female, Malawi, T7). Similarly, in another instance, the employer brought the participant into Ireland on a tourist visa and 'never converted it into employment' (Female, Pakistan, T9). 
Another participant reported that on entering the country and obtaining the visa, the employer presented her passport on her behalf, allowing him to maintain control of the passports and the interaction with the immigration authorities. She wondered, 'Why you didn't ask the owner of the passport to show their passport?' She felt that the dealings with the authorities were 'very easy' for him 'because he's Irish' (Female, Philippines, T8). One employer also insisted on accompanying the worker each time she went to report to the immigration authorities, meaning that she felt that she could not speak to them openly (Female, Malawi, T7). This suggests that it would be useful for Ireland to adopt the practice of other jurisdictions such as England and Wales whereby workers are interviewed in private, on arrival and periodically during the duration of their work permit, to advise them of rights and entitlements and of who to contact in case of labour rights issues or other difficulties (Mullally and Murphy 2014).

\section{Barriers to reporting via the employment enforcement authorities}

The legal relationship between human trafficking and employment law is important, but problematic in the current regulatory environment in Ireland. Research from other jurisdictions indicates that immigration services and labour inspectors play a 'crucial' role in detecting instances of trafficking for forced labour (Skrivankova 2010). The design of Irish immigration and employment enforcement mechanisms, however, means that migrant workers are likely to fear either losing their work permit, not having their work permit renewed, or being deported if detected while undocumented. As one woman remarked:

I know there are so many people who are in exploitation but they are scared to come out because there's not enough support. Some of them are illegal and they think that if they maybe come out they are going to be deported (Female, Malawi, T7).

This fear of deportation is well-founded: employment and immigration enforcement are completely intertwined in the Irish context. The labour inspectorate (WRC) has enforcement functions under the Employment Permits Acts 2003-14, and as such is an extension of the immigration authorities (WRC 2017: 11). Tellingly, all participants reported that it was MRCI (rather than labour inspectors or any other state body) who first gave them information on their employment rights and encouraged them to seek redress. As one interviewee noted:

It's only when I came out of the situation ... I came to know everything about the employee rights, about the immigration. The MRCI that make me to know everything. To know about employment issue (Female, Nigeria, T1).

None of the participants were identified as victims of trafficking through the work of the labour inspectorate, nor did any of the participants (except one) report interaction with the labour enforcement machinery until after they had escaped their trafficking situation. It appears that participants were only enabled to report their issues to the WRC through the advice and support of MRCI (Female, Pakistan, T9).

A related problem is that, aside from their deportability, undocumented workers remain excluded from employment protections under Irish law. The current legal position in Ireland is that undocumented workers cannot generally enforce employment 
rights due to the illegality underlying the contract of employment, although there were some obiter dicta comments in the recent Supreme Court judgment in Hussein v The Labour Court ([2012] IEHC 364; [2015] IESC 58) to the effect that this might be reviewed in an appropriate case, in light of the principle of proportionality ([2015] IESC 58, para. 52, per Murray J). The legal position is borne out in the experiences of some participants: one individual stated that she had been through a process with the WRC who had told her 'we are going to help you from the time you are a student, work as a student up to the time you were into only one year so' (Female, South Africa, T5) However, other participants (Female, Pakistan, T9; Female, Malawi, T7) were awarded money even though completely undocumented. In practice, many of those interviewed appear to have been constantly in and out of 'legality', with the necessary permissions in place for some of the period during which they had worked and been exploited. None of those interviewed appeared to have successfully received the full amount owed to them, even if awarded by a tribunal of court. In some cases, the employer could not be contacted (Female, Nigeria, T1), had left the country (Female, South Africa, T 3) and in others simply had not paid the award (Female, Malawi, T7).

The interviews revealed a working relationship between the police, the employment enforcement authorities and the NGO in question (MRCI). In some cases, the immigration police had advised the victim to contact MRCI (Female, Nigeria, T1), and vice versa (Female, Philippines, T13). In the case of eight participants, MRCI had assisted the participants to seek redress through the employment enforcement machinery. One participant reported that she had come into contact with the labour inspectorate through Sunday meetings organized by the NGO, at which the inspectors were giving information on work-related rights. Although these informal contacts are valuable, a more planned and formal collaboration between the Gardaí, labour inspectors, NGOs and the immigration authorities would help to ensure that migrant workers feel comfortable reporting poor working conditions, breaches of employment law and other offences irrespective of their legal status or lack thereof. Such a multi-agency strategy would, however, require the authorities to identify all victims of trafficking without discrimination, regardless of their immigration status or nationality (ICI 2017: 3). In practice, this would require a 'firewall' between labour inspectors and immigration authorities, in line with international best practice (Noll 2010: 143-7; FRA 2011: 11).

\section{Coercion and threats}

Once victims are at their destinations, 'traffickers use a variety of psychological and physical methods to get them to stay' in their exploitative situations (McCarthy 2014: 231). The extent to which traffickers exercise control over their victims has been well documented in victim accounts (Aronowitz 2017: 106). These acts of coercion include physical beatings, death threats addressed to the victim or his or her family and 'denunciation to the police or immigration authorities when the victim's residence or work status is illegal' (Belser 2005: 4). In line with international experience that human trafficking operations are meticulously planned and orchestrated to make victims vulnerable and to create a climate of fear and dependence (Shelley 2010: 206; Farrell 2011: 72 ), the individuals we interviewed reported a variety of combinations of these threats. The level of control in one case led the interviewee to state: 'I felt like she owns me even' (Female, South Africa, T2). 
Gadd and Broad (2018: 13) note that 'being physically forced to work is rare. More commonly, poorly paid workers become imbricated in a succession of processes that move them through a continuum of exploitation that is facilitated by under-regulation of the labour market and immigration law'. In the study, this is highlighted in the most commonly used threat, deployed against one-third of the workers, that of repatriation or deportation. One interviewee was threatened with being sent back to her country of origin after three years in Ireland: 'One day they wanted to take me back to South Africa. So, they keep on telling me that you are going home' (Female, South Africa, T12). In another case, the victim had this fear of deportation instilled by the employer and felt that she had no choice but do whatever her employer instructed (Female, Nigeria, T1). A participant, who wanted to leave her exploitative situation to find other work, stated that the employer threatened to 'just report me to the immigration' (Female, South Africa, T2). Another interviewee feared physical harm: 'I know him, that he will beat me or . . . so I was scared to go'. The Filipina participant, similar to trafficking victims in other jurisdictions (Segrave 2016), was not only threatened with deportation (Farrell 2014: 6), but also with death if she attempted to escape. She gave a stark account of the power and control exercised by her captor:

I know the Filipino mentality ... it's like, they're just they, if they want to kill you they just kill you . . . Because my employer said, if we want to kill you ... we're going to hire a man who will kill you we can just do that.

Trafficked persons are in 'a particularly vulnerable position, as the perpetrators often know the victims and their relatives very well, which makes them an easy target for reprisals if the victims testify' (Rijken 2009: 217). One interviewee, for instance, received no direct threats, but her traffickers contacted her family to inquire about her whereabouts (Female, South Africa, T14). Another participant stated that the employer continued to threaten her parents in her home country (Female, South Africa, T4). These experiences are consistent with studies conducted with trafficking victims in other jurisdictions, which revealed similar concerns (Bales and Soodalter 2009: 119; De Chesnay 2013: 313).

\section{Means of control}

Victims of labour trafficking are not only reluctant to report the crime 'due to fears of reprisals by their traffickers' (Newton et al. 2008: 1). Other forms of control exercised by traffickers, consistent with international experience (Aronowitz 2001: 177), included confiscating passports and other documents, and some victims experienced restricted movement (Female, South Africa, T2; Female, Philippines, T13). One participant reported that his movement was restricted even within the workplace: 'Anytime watching for camera, I go to the kitchen and he is saying "he is in the kitchen and how long he is sitting. What I am eating"' (Male, India, T10). Imposed isolation and deprivation of 'any means of unsupervised movement' were shown to be powerful tools for traffickers (Burke 2013). This isolation also resulted in victims being unable to interact with other people (Female, Malawi, T7). These control techniques may include physical, social and linguistic isolation, as well as restricting the victim's 'exposure to and understanding of the outside world' (Baldwin et al. 2015: 1174). These reflected the experiences reported by the interviewees. One victim said, e.g., that she 'was not allowed to call, visit, or talk 
to anyone' (Female, South Africa, T12), whereas another interviewee was 'not allowed to go out, just stay in the house' (Female, Philippines, T13). The latter is an example of a case where 'the threat of denunciation and deportation' culminated in a situation where the victim was not 'physically constrained' but subjectively perceived 'a lack of freedom of movement' (Andrees 2008: 25). All the participants felt that they had 'no real and acceptable alternative' but to submit to the abuse (Stoyanova 2013: 66).

\section{Reasons for reluctance to approach law enforcement officials}

Immigration status and control techniques are not the only factors that make trafficked victims reluctant to approach authorities, immigration officials or NGOs for help and assistance (Wylie and McRedmond 2010: 177). The majority of participants, such as trafficking victims in other jurisdictions (Winterdyk et al. 2011: 487; Allum and Gilmour 2012: 498), did not 'approach the law enforcement officials voluntarily and directly as victims of crime' (Roth 2011: 7). Trafficking victims fear disclosing their status to the authorities for numerous reasons (Gielen and Roopnarine 2004: 393). As mentioned earlier, these include inter alia the belief that they have 'committed a crime and may be subject to arrest and imprisonment if they contact the authorities' ( United Nations Office on Drugs and Crime 2008: 255; Roth 2011: 7). One interviewee, for instance, was initially in fear that she would be exposed to the risk of arrest or deportation to her country of origin: 'At first I was I was scared cos I thought maybe they will arrest me or take me back home' (Female, South Africa, T14). Victims, depending on their source country, may also distrust the police and the authorities (Bosworth et al. 2011: 774; Cao et al. 2016). One of the South African interviewees was concerned: 'if I go to the Guards, I'll lose everything, my child won't go to school, won't have money to go to school, myself I won't survive because I'm not working' (Female, South Africa, T12). Such concerns are inevitably exacerbated when the victims do not speak the local language, have little or no knowledge of the destination country and have no legal status (Mahnovski et al. 2006: 61; Cullen-DuPont 2009: xi; Renzetti et al. 2011: 167). Overall, the participants reported being very isolated having little contact with or knowledge of wider Irish society (Female, South Africa, T12; Female, Philippines, T13). One person suggested that a way to reach these isolated individuals could be through 'adverts like documentaries on the television or on the radio. The police, they give a contact number where you can contact somebody' (Female, Malawi, T7).

\section{Victim Protection and Support}

\section{Police protection}

Stoyanova (2011) notes that 'it is widely recognised that persons who become subjects of human trafficking are in need of assistance and protection' (778). In this context, the law enforcement response is particularly important. Although two participants reported that the local Gardaí 'did nothing' (Male, Pakistani, T11) or 'couldn't help' (Female, South Africa, T2), the remaining interviewees were satisfied with the support provided by rank-and-file police and the staff of the Garda National Immigration Bureau (Female, Malawi, T7; Female, South Africa, T12). Skrivankova (2010) notes that 
a 'sophisticated' response is needed to deal with this 'complex social phenomenon' (16) and the level of assistance received by the interviewees ranged from the provision of a police contact number (Female, Philippines, T13) to the removal of the victim from her trafficking situation (Female, South Africa, T14). Trafficking victims are generally reluctant to trust the police (Piotrowicz et al. 2018), partly due to prejudices against law enforcement agencies in their home countries (Gunderson 2012: 161; BuschArmendariz et al. 2017: para. 5.14), but the behaviour and attitude of the Gardaí was 'crucial for trust building' (Piotrowicz et al. 2018). As one participant put it: 'I know they protect me. Because the, the police here in Ireland, I know they are very good' (Female, Philippines, T13). This is not to suggest that the provision of assistance and protection could not be improved in certain respects (Female, South Africa, T12; Female, South Africa, T15), but it does appear that individual police officers were successful in gaining the trust of participants which is 'an important first step in providing assistance' (Negi and Furan 2010: 120). One interviewee found that the immigration Garda 'treated me like a human being' (Female, South Africa, T2). Crucially, these victims did not report feeling pressurized to pursue the case (Female, Philippines, T13) or to stay in Ireland, or conversely, to leave (Female, South Africa, T14).

\section{Accommodation and support}

The practice of housing trafficking victims in accommodation centres for asylum seekers has been criticized by GRETA and a number of national NGOs (ICI 2014: 3; GRETA 2017: 62). Similarly, the interviewees felt that the Reception and Integration Agency direct provision centres are not an appropriate environment for trafficking victims, and that separate services and accommodation are required. One interviewee pointed out that 'you feel like it's not safe there, because they're very ... stress and all that' (Female, South Africa, T12), whereas another participant suggested 'maybe separate them [asylum seekers] because their stories are quite different' (Female, South Africa, T15). One participant reported that she did not really understand where she was, and described feeling very traumatized and isolated: 'I wasn't talking a lot you know, some people they were very nice and they were friendly and they wanted to be friends with me but I was very vulnerable' (Female, Kenya, T6). This mirrored the confusion experienced by another woman, who also did not precisely understand where she was when she was in the direct provision centre.

More broadly, research in other jurisdictions reveals that '[s]afe accommodation for trafficked persons contributes to both physical security and mental recovery by giving them the feeling that their needs are being looked after and their worries are being taken seriously' (Friman and Reich 2007: 124). However, consistent with research on the conditions in the Irish refugee reception system (Thornton 2007), the accommodation and support provided in the direct provision centres appears to be at the level of subsistence only. Indeed, many participants valued the basic amenities provided (Female, South Africa, T4; Female, South Africa, T12). One person noted: 'It is good. I mean, I'm saying this comparing it to a man who is on the street, a man, woman or child who is on the street ... It is warm. There is good heating. There are shared showers . . . I don't want to sound ungrateful. Em, because as basic shelter it was okay' (Female, South Africa, T2). However, this interviewee also revealed the disempowering effects of 
this type of provision, citing the lack of 'control of your life', and describing queuing at mealtimes as 'like prisoners holding the tray, metal cereal bowls or whatever' (Female, South Africa, T2).

Leaving aside the wider debate about the deficiencies of the direct provision system generally (Thornton 2007), a dedicated accommodation unit for trafficking victims in Ireland, which would go beyond the level of 'basic shelter' and be tailored to the needs of trafficking victims, is clearly necessary. So what are those needs? The lack of legal advice provided to those residing in reception centres was raised (Female, South Africa, T2) as was the absence of counselling and organized meaningful activities. One interviewee who was accommodated in a direct provision centre suggested establishing a support group 'maybe just with the other victims' (Female, South Africa, T14), whereas another expressed the view that it would be beneficial for individuals if counselling was provided on-site, or even someone 'just to encourage them, give them hope' (Female, South Africa, T15). Other suggestions included English classes, training and skills opportunities, clubs (Female, Nigeria, T3) and sports activities (Female, South Africa, T15), and more information on Ireland and what life is like after the accommodation centre (Female, Kenya, T6). However, one participant did report a positive experience with her Health Service Executive caseworker after she had left her trafficking situation: 'He's very good anyway; he helped me when I went to social welfare. Because I have the allowance, you know; the government gave me the allowance as well' (Female, Philippines, T13). The same person was glad that she had been offered the opportunity to complete a further education training course. On a more long-term basis, victims need assistance with finding accommodation after the initial period of recovery. One participant remarked that one of the hardest things was finding a place to rent given the high rents and housing shortage in Dublin (Female, South Africa, T14). Overall, MRCI provided wide-ranging support to victims, which included advice and counselling, organizing emergency accommodation, legal advice and document assistance, as well as pastoral-type care. One interviewee noted that on leaving her trafficking situation, 'I get the support more from MRCI than I did from Government because when I left there I was really stranded, like I didn't know where to go' (Female, Nigeria, T3).

\section{Victims' Perspectives on Assisting Authorities}

\section{Interaction of trafficking and immigration frameworks for trafficked persons assisting the} authorities

The importance of being allowed to remain and work in the State-a common theme throughout all the interviews - was highlighted by one interviewee, who stated that she did not really want to pursue an employment claim, 'just to stay in Ireland and work . . . I said even I don't have money, only I want to stay here to work because I can earn the money more than they can give to me' (Female, Philippines, T8). In practice, however, there was little certainty or transparency surrounding the type of immigration status granted to the interviewees, whether it would be renewable, and for how long. Some participants reported renewing their temporary permission ('stamp four') every six months or a year, with one interviewee finally obtaining naturalization (Female, Malawi, T7). The pattern was that precarious and short-term immigration statuses were 
granted to victims on a rolling basis. This in itself is problematic. The precarity created by short-term, conditional migration statuses has been shown to reinforce the unequal power relations between migrant workers and their employers (Mantouvalou 2015), and 'provides unscrupulous employers with mechanisms of control they might not otherwise have' (Mullally 2014: 147). In this situation, the victim is potentially exposed to further-state-constructed-vulnerability to labour exploitation (Murphy 2015: 31). One interviewee pointed out that the short-term nature of the visa made it difficult to visit her family as it would lead the Filipino authorities to question the legitimacy of the papers (Female, Philippines, T13).

\section{Ineffective criminal compensation mechanisms}

One reason put forward for pursuing a human trafficking case was reparation in the form of "monetary compensation for damages and the harm caused by the human rights violation' (Gebrewold et al. 2017). As the participant put it, 'I don't want my three years, three and a half years just goes like that without any compensation' (Female, Philippines, T13). This is a pertinent remark in light of the recommendation in the $S N A P$, which aims 'to ensure that all victims are aware of and have access to existing compensation schemes' and that 'guides for victims contain information outlining rights to compensation' (DJE 2016: 87). Although MRCI has been successful in helping labour trafficking victims obtain recompense through the Labour Court for breaches of their employment rights, these awards amount only to repayment of some of the monies owed as opposed to compensation for criminal damages incurred. To date, no labour trafficking victim has accessed the existing criminal compensation mechanisms in Ireland and significant barriers persist (GRETA 2017: 45-6). Receiving compensation is not only important in terms of the financial component that assists trafficking victims in rebuilding their lives, but also in terms of alleviating practical concerns such as obtaining appropriate long-term accommodation (Female, South Africa, T14).

\section{Motivations for pursuing prosecution}

In the case of the participants interviewed for this study, each had decided to cooperate with the authorities: in most cases a criminal prosecution is not taken because the DPP decides that there is insufficient evidence (Female, Malawi, T7). The reasons for pursuing prosecutions against their traffickers, akin to other jurisdictions, varied (Segrave et al. 2018: 115-31). These included punishing traffickers, seeking restitution, protecting future victims and wishing to remain in the jurisdiction. One interviewee stated that she wanted to alleviate the potential suffering of others facing a similar plight: 'I don't want them to bring another girl here' (Female, South Africa, T14). Such views are gaining increased attention in the trafficking literature (Winterdyk et al. 2011: 80) and were echoed by another participant: 'I was afraid that they will bring someone else and she will go through the same thing I went through, so I want them to learn that lesson that this is not the right thing'. This victim also expressed a desire to ensure that her trafficker was sufficiently punished: 'I want them to be punished because I was not the only one . . . went through that. The lady who, who I came after, and someone else came after me'. The decision to pursue a prosecution was particularly difficult in 
cases where relatives were involved (Female, South Africa, T12). Victims of human trafficking, however, may be 'in a situation where they are not emotionally stable enough to cooperate in an investigation' (Farrell and Pfeffer 2014: 60), and thus co-operating with the authorities in the prosecution of traffickers should not be a prerequisite in order to receive residence permits and services, or access rights (Rijken 2009: 212).

\section{Conclusion}

This research makes clear that trafficking victims are an indispensable source of information about the best ways in which to meet their needs through law and policy initiatives. Victims' perspectives are too often absent from the development of policies and measures that directly affect them (Jordan 2002: 29; Goodey 2005: 116-7), as well as scholarly work that seeks to understand the processes involved. As experts on their own needs and experiences, victims must be given a central role in the development of evidence-based measures to combat trafficking and both assist and empower those impacted by it. One significant barrier to a genuinely participative and inclusive approach to modern slavery policy, however, is the wider context: migrant workers who encounter labour exploitation-if they come into contact with the authorities at all-are more likely to be identified as 'offenders' in breach of immigration law than 'victims' deserving of protection (Turek 2013: 83). ${ }^{12}$ The difficulties involved in constructing a victim-centred modern slavery regime within the broader context of a 'hostile environment' to immigration, focussed on the presumed interests of the state, are placed in stark relief by this article.

Victims' experiences are also critical to the assessment of the extent to which states are, in practice, fulfilling their duties towards victims under international and EU law. These testimonies shed light on particular strengths and shortcomings within the Irish anti-trafficking system and reveal the need for specialized training in identification. They also demonstrate that an effective channel for immigration, employment and general law enforcement authorities to interact with potential victims is required. Most of these matters are covered in principle by state obligations under the Council of Europe Anti-Trafficking Convention, the ECHR and EU Directives, but clearly need to be improved upon at the level of implementation to achieve the holy grail of the 'practical and effective' (Airey $v$ Ireland [1979] 2 E.H.R.R. 305) enjoyment of the rights contained in those legal instruments. Thus, our research supplements and informs existing analyses of the black-letter law of modern slavery.

Yet despite the usefulness of qualitative research as a basis for 'good evidencebased, victim-centred social policy' (Goodey 2005: 114), two key findings of this article illustrate the complexities and tensions inherent in devising victim-centred policy in this field. First, it emerges strongly that the lived experiences of the participants cut across the spheres of employment, criminal and immigration law, with each of these regulatory systems impacting on their lives in important ways. Practical difficulties with enforcing employment awards, access to criminal compensation and

\footnotetext{
${ }^{12}$ See also, e.g., The Guardian, 'Victims of crime being handed over to immigration enforcement' (14 May 2018), https:// amp.theguardian.com/uk-news/2018/may/14/victims-crime-handed-over-police-immigration-enforcement?__twitter_ impression=true; Victoria Derbyshire, BBC Two, 14 May 2018.
} 
precarious short-term immigration statuses are just some of the issues highlighted. This suggests that it is not possible to comprehensively address the needs of victims of labour exploitation through a specific anti-trafficking or 'modern slavery' framework alone. Rather, the broader legal and regulatory context must also be interrogated to understand-among other things-how it potentially facilitates exploitation and enables or restricts access to remedies. Equally, a comprehensive conceptual framework must situate trafficking and modern slavery within these broader legal and administrative processes.

Secondly, there appears to be a gap between what victims of severe labour exploitation want in the medium term (a priority being access to an immigration status that would allow them to work) and the limits to that which the State is required, and willing, to provide (temporary residence permits that may be contingent on co-operation with the authorities). By enabling a more nuanced understanding of victims' needs and perspectives, it is hoped that this study will help bridge the gulf between policy and practice and 'shift public debate away from the binary thinking structures that conflate trafficking with lax immigration control' (Gadd and Broad 2018: 16).

Overall, this research supports the conclusion that employer exploitation works together with migration and labour policies that 'curtail migrant workers' rights and bargaining power . . . rendering precarious workers unfree at particular junctures in their sojourns' (Yea and Chok 2018: 2). Moreover, as Coghlan and Wylie, Anderson, and Strauss have all observed in different ways, anti-trafficking measures have the "undesirable consequence of drawing a line between the "deserving" and the "undeserving" exploited, thereby denying justice to many who migrate for work and find their rights and dignity violated in the process' (Coghlan and Wylie 2011: 1513). Nonetheless, the experiences reported to us also suggest that, despite the 'excessive positivity' (Gadd and Broad 2018) of the anti-trafficking paradigm, it is of some practical benefit to an individual to be identified as a victim of labour trafficking-for the lucky few who obtain that status. The key practical benefits identified by the participants in this study were being allowed to stay and work in the country (a permission that appeared to be often renewed in practice) and the provision of basic shelter in the immediate aftermath of escaping exploitation. This 'bottom-up' insight is beneficial in terms of developing existing conceptual frameworks, which may conceive trafficking frameworks to be irredeemably damaging at the level of principle.

\section{Funding}

This work was supported by the Irish Research Council.

\section{Acknowledgements}

We are grateful to Iman Anbar, Clare Cowley, Claire Hamilton, Edel McGinley, Jane O'Connell, Daniel O’Dowd, Dearbhla Ryan and Suzanne Scott for their advice, comments and practical assistance. We are also especially obliged to all the interviewees who participated in this study. 


\section{REFERENCES}

Agustin, L. M. (2005), 'Migrants in the Mistress's House: Other Voices in the "“Trafficking” Debate', Social Politics: International Studies in Gender, State and Society, 12: 96-117.

Allain, J. (2012), Slavery in International Law: Of Human Exploitation and Trafficking. Brill.

Allum, F. and Gilmour, S. (2012), Routledge Handbook of Transnational Organised Crime. Routledge.

Anderson, B. (2012), 'Where's the Harm in That? Immigration Enforcement, Trafficking, and the Protection of Migrants' Rights', American Behavioural Scientist, 56: 1241-57.

Andrees, B. (2008), Forced Labour and Trafficking in Europe: How People Are Trapped In, Live Through and Come Out. International Labour Office.

Anti-Human Trafficking Unit (AHTU). (2009). Summary Report of Trafficking in Human Beings in Ireland for 2009. Department of Justice, Equality and Law Reform.

Aronowitz, A. A. (2001), 'Smuggling and Trafficking in Human Beings: The Phenomenon, the Markets that Drive it and the Organisations that Promote it', European Journal on Criminal Policy and Research, 9: 163-95.

-. (2017), Human Trafficking: A Reference Handbook. ABC-CLIO.

Baldwin, S. B., Fehrenbacher, A. E. and Eisenman, D. P. (2015), 'Psychological Coercion in Human Trafficking: An Application of Biderman's Framework', Qualitative Health Research, 25: 1171-81.

Bales, K. and Soodalter, R. (2009), The Slave Next Door. University of California Press.

Belser, P. (2005), Forced Labour and Human Trafficking: Estimating the Profits. International Labour Office.

Bosworth, M., Hoyle, C. and Dempsey, M. M. (2011), 'Researching Trafficked Women: On Institutional Resistance and the Limits to Feminist Reflexivity', Qualitative Inquiry, 17: 769-79.

Burke, M. C. (ed.) (2013), Human Trafficking: Interdisciplinary Perspectives. Routledge.

Busch-Armendariz, N. B., Nsonwu, M. and Heffron, L. C. (2017), Human Trafficking: Applying Research, Theory, and Case Studies. SAGE.

Cameron, S. and Newman, E. (eds) (2008), Trafficking in Humans: Social, Cultural and Political Dimensions. United Nations University Press.

Cao, L., Huang, L. and Sun, I. Y. (2016), Policing in Taiwan. Routledge.

Coghlan, D. and Wylie, G. (2011), 'Defining Trafficking/Denying Justice? Forced Labour in Ireland and the Consequences of Trafficking Discourse', Journal of Ethnic and Migration Studies, 37: 1513-26.

Council of Europe Convention on Action against Trafficking in Human Beings [2005], ETS No. 197.

Cullen-DuPont, K. (2009), Human Trafficking. Facts on File.

Davies, J. (2018), 'From Severe to Routine Labour Exploitation: The Case of Migrant Workers in the UK Food Industry', Criminology and Criminal Justice, 1-17. doi:10.1177/1748895818762264

De Chesnay, M. (ed.) (2013), Sex Trafficking: A Clinical Guide for Nurses. Springer.

Department of Justice and Equality (DJE). (2015), Roundtable on Identification of Victims of Human Trafficking. DJE.

- (2016), Second National Action Plan to Prevent and Combat Human Trafficking in Ireland. DJE.

Directive (2004). 2004/81/EC of 29 April 2004 on the residence permit issue to third-country nationals who are victims of trafficking in human beings or who have been subject of an action to facilitate illegal immigration, who cooperate with the competent authorities [2004] OJ L 262/19. 
DOYLE ET AL.

Directive (2011). 2011/36/EU of 5 April 2011 on preventing and combatting trafficking in human beings and protecting its victims [2011] OJ L 101/1.

Di Nicola, A., Cauduro, A., Lombardi, M. and Ruspini, P. (2009), Prostitution and Human Trafficking: Focus on Clients. Springer.

Elliot, J. (2014), The Role of Consent in Human Trafficking. Routledge.

Emirbayer, M. and Desmond, M. (2012), 'Race and reflexivity', Ethnic and Racial Studies, 35: 574-99.

European Union Fundamental Rights Agency (FRA). (2011), Fundamental Rights of Migrants in an Irregular Situation in the European Union. Publications Office of the European Union.

- (2015), Severe Labour Exploitation: Workers Moving within or into the European Union. Publications Office of the European Union.

FArrell, A. (2014), 'Environmental and Institutional Influences on Police Agency Responses to Human Trafficking', Police Quarterly, 17: 3-29.

Farrell, C. (2011), Human Trafficking. ABDO Publishing Company.

Farrell, A. and Pfeffer, R. (2014), 'Policing Human Trafficking: Cultural Blinders and Organizational Barriers', The Annals of the American Academy of Political and Social Science, 653: 46-64.

Friesendorf, C. (2007), 'Pathologies of Security Governance: Efforts Against Human Trafficking in Europe', Security Dialogue, 38: 379-402.

Friman, H. R. and Reich S. (eds) (2007), Human Trafficking, Human Security, and the Balkans. University of Pittsburgh Press.

Fudge, J. and Strauss, K. (eds) (2013), Temporary Work, Agencies, and Unfree Labour: Insecurity in the New World of Work. Routledge.

GADD, D. and BROAD, R. (2018), 'Troubling recognitions in British responses to modern slavery', The British Journal of Criminology. doi:10.1093/bjc/azx082: 1-22.

Gallagher, A. (2010), The International Law of Human Trafficking. Cambridge University Press.

Gebrewold, B., Kostenzer, J. and Muller, A.T. (2017), Human Trafficking and Exploitation: Lessons from Europe. Routledge.

Gielen, U. P. and Roopnarine, J. L. (eds) (2004), Childhood and Adolescence: Cross-Cultural Perspectives and Applications. Praeger.

Goodey, J. (2005), Victims and Victimology: Research, Policy and Practice. Pearson Education Limited.

Group of Experts on Action against Trafficking in Human Beings (GRETA). (2015), Report Concerning the Implementation of the Council of Europe Convention on Action against Trafficking in Human Beings by Ireland. Council of Europe.

- (2017), Report Concerning the Implementation of the Council of Europe Convention on Action against Trafficking in Human Beings by Ireland: Second Evaluation Round. Council of Europe.

Gunderson, C. (2012), Human Trafficking: The Trafficking of Women in Northern Germany for the Purpose of Sexual Exploitation. LIT.

Hathaway, J. C. (2008), 'The Human Rights Quagmire of "Human Trafficking”, Virginia Journal of International Law, 49: 1-59.

Immigrant Council of Ireland (ICI). (2011), Asylum Seeking Victims of Human Trafficking in Ireland: Legal and Practical Challenges. ICI.

- (2014), Summary on the Needs of Adult Victims of Sex Trafficking in Ireland. ICI.

—. (2017), Submission to the US State Department Trafficking in Persons Report 2017. ICI. 
International Labour Organization (ILO). (1930), Forced Labour Convention, 1930 (No. 29). ILO. —. (2017), Global Estimates of Modern Slavery: Forced Labour and Forced Marriage. ILO and Walk Free Foundation.

Irish Human Rights and Equality Commission (IHREC). (2016), Submission to GRETA in Advance of Its Second Evaluation Round of Ireland. IHREC.

Jordan, A. D. (2002), 'Human Rights or Wrongs? The Struggle for a Rights-Based Response to Trafficking in Human Beings', Gender and Development, 10: 28-37.

Joyce, C. and Quinn, E. (2014), Identifying Victims of Trafficking in Human Beings in Asylum and Forced Return Procedures: Ireland. European Migration Network.

Kilcommins, S., Leahy, S., Moore Walsh, K. and Spain, E. (2018), The Victim in the Irish Criminal Process. Manchester University Press.

Mahnovski, S., Akramov, K. T., Karasik, T. W. and Karasik, T. (2006), Economic Dimensions of Security in Central Asia. RAND Project Air Force.

Mantouvalou, V. (2015), “'Am I Free Now?” Overseas Domestic Workers in Slavery', Journal of Law and Society, 42: 329-57.

Migrant Rights Centre Ireland (MRCI). (2014), Trafficking for Forced Labour in Cannabis Production: The Case of Ireland. MRCI.

Milano, V. (2017), 'The European Court of Human Rights' Case Law on Human Trafficking in Light of L.E. $v$ Greece: A Disturbing Setback?', Human Rights Law Review, 17: 701-27.

McCarthy, L. A. (2014), 'Human Trafficking and the New Slavery', Annual Review of Law and Social Science, 10: 221-42.

Mullally, S. (2014), 'Migration, Gender, and the Limits of Rights', inR. Rubio-Marin, ed., Human Rights and Immigration. Oxford University Press.

Mullally, S. and Murphy, C. (2014), 'Migrant Domestic Workers in the UK: Enacting Exemptions and Rights', Human Rights Quarterly, 36: 397-427.

Murphy, C. (2015), 'Enforcing Employment Standards for Undocumented Migrant Domestic Workers in the UK and Ireland: Rethinking Illegality in Zones of Invisibility', Journal of Immigration, Asylum and Nationality Law, 29: 29.

Negi, N. J. and Furan, R. (2010), Transitional Social Work Practice. Columbia University Press.

Newton, P. J., Mulcahy, T. M. and Martin, S. E. (2008), Finding Victims of Human Trafficking. National Opinion Research Center.

NolL, G. (2007), 'The Insecurity of Trafficking in International Law', in V.Chetail, ed., Mondialisation, Migration et Droits de L'homme: le Droit International en Question. Bruylant.

- (2010), 'Introduction: The Laws of Undocumented Migration'. European Journal of Migration and Law, 12: 143-47.

O'Connell-Davidson, J. and Anderson, B. (2006), 'The Trouble with Trafficking', in C. van den Anker and C. J. Doomernik, eds, Trafficking and Women's Rights. Palgrave.

Ollus, N. (2015), 'Regulating Forced Labour and Combating Human Trafficking: The Relevance of Historical Definitions in a Contemporary Perspective', Crime, Law and Social Change, 63: 221-46.

Organization for Security and Co-Operation in Europe (OSCE). (2011), Trafficking in Human Beings: Identification of Potential and Presumed Victims: A Community Policing Approach. OSCE.

- . (2013), Office of the Special Representative and Co-ordinator for Combating Trafficking in Human Beings. OSCE.

Paz-Fuchs, A. (2016), 'Badges of Modern Slavery', Modern Law Review, 79: 757-85.

Ranstev, v., Cyprus And Russia. (2010), Application No. 25965/04. 
DOYLE ET AL.

Renzetti, C. M., Edleson, J. L. and Bergen, R. K. (2011), Companion Reader on Violence Against Women. SAGE.

Rijken, C. (2009), 'A Human Rights Based Approach to Trafficking in Human Beings', Security and Human Rights, 3: 212-22.

Roth, V. (2011), Defining Human Trafficking and Identifying Its Victims. Martinus Nijhoff.

Segrave, M. (2016), Human Trafficking. Routledge.

Segrave, M., Milivojevic, S. and Pickering, S. (2018), Sex Trafficking and Modern Slavery: The Absence of Evidence. Routledge.

Shelley, L. (2010), Human Trafficking: A Global Perspective. Cambridge University Press.

Skrivankova, K. (2010), Between Decent Work and Forced Labour: Examining the Continuum of Exploitation. Joesph Rowntree Foundation.

Stapleton, P. (2011), 'Human Trafficking in Ireland: Identifying Victims of Trafficking', Proceedings of the 2nd Annual Critical Social Thinking Conference. University College Cork.

Stoyanova, V. (2011), 'Complementary Protection for Victims of Human Trafficking under the European Convention on Human Rights', Goettingen Journal of International Law, 3: $777-817$.

—. (2013), 'The Crisis of a Definition: Human Trafficking in Bulgarian Law', Amsterdam Law Forum, 5: 64-79.

— (2014), 'Article 4 of the ECHR and the Obligation of Criminalising Slavery, Servitude, Forced Labour and Human Trafficking', Cambridge Journal of International and Comparative Law, 3: 407-43.

- (2017), Human Trafficking and Slavery Reconsidered. Cambridge University Press.

Strauss, K. (2012), 'Coerced, Forced and Unfree Labour: Geographies of Exploitation in Contemporary Labour Markets', Geography Compass, 6: 137-48.

Thornton, L. (2007), 'Upon the Limits of Rights Regimes: Reception Conditions of Asylum Seekers in Ireland', Refuge: Canadian Periodical on Refugee Studies, 24: $86-100$.

Turner, I. (2015), 'Human Rights, Positive Obligations, and Measures to Prevent Human Trafficking in the United Kingdom', Journal of Human Trafficking, 1: 296-317.

Tyldum, G. and Brunovskis, A. (2005), 'Describing the Unobserved: Methodological Challenges in Empirical Studies on Human Trafficking', International Migration, 43: $17-34$.

United Nations. (2000). Protocol to Prevent, Suppress and Punish Trafficking in Persons, Especially Women and Children, supplementing the United Nations Convention Against Transnational Organized Crime.

United Nations Office on Drugs and Crime (UNODC). (2008), Toolkit to Combat Trafficking in Persons. United Nations.

United States Department of State (USDS). (2017), Trafficking in Persons Report. USDS.

United States Department of State (USDS). (2018). Trafficking in Persons Report. USDS.

VAn Liempt, I. and Bilger, V. (eds) (2009), The Ethics of Migration Research Methodology: Dealing with Vulnerable Immigrants. Sussex Academic Press.

Workplace Relations Commission (WRC). (2017), Report on WRC Enforcement of the Atypical Worker Permission Scheme in the Irish Sea Fishing Fleet. WRC.

World Health Organization (WHO). (2003), WHO Ethical and Safety Recommendations on Interviewing Trafficked Women. WHO. 
Winterdyk, J., Perrin, B. and Reichel, P. (2011), Human Trafficking: Exploring the National Nature, Concerns, and Complexities. CRC Press.

Wylie, G. and McRedmond, P. (2010), Human Trafficking in Europe: Character, Causes and Consequences. Palgrave Macmillan.

YeA, S. and CHок, S. (2018), 'Unfreedom Unbound: Developing a Cumulative Approach to Understanding Unfree Labour in Singapore', Work, Employment and Society, 1-17. doi:10.1177/09500017017738956 